\begin{tabular}{|l|l|l|}
\hline \multicolumn{2}{|c|}{ PublisherInfo } \\
\hline \hline PublisherName & $:$ & BioMed Central \\
\hline \hline PublisherLocation & $:$ & London \\
\hline \hline PublisherImprintName & $:$ & BioMed Central \\
\hline \hline
\end{tabular}

\title{
Destruction before salvation
}

\begin{tabular}{|l|l|l||}
\hline \multicolumn{2}{|c|}{ ArticleInfo } \\
\hline \hline ArticleID & $:$ & 3743 \\
\hline \hline ArticleDOI & $:$ & $10.1186 /$ gb-spotlight-20000814-02 \\
\hline \hline ArticleCitationID & $:$ & spotlight-20000814-02 \\
\hline \hline ArticleSequenceNumber & $:$ & 180 \\
\hline \hline ArticleCategory & $:$ & Research news \\
\hline \hline ArticleFirstPage & $:$ & 1 \\
\hline \hline ArticleLastPage & $:$ & 2 \\
\hline \hline & & RegistrationDate : 2000-08-14 \\
ArticleHistory & $:$ & OnlineDate \\
\hline \hline ArticleCopyright & $:$ & BioMed Central Ltd2000-08-14 \\
\hline \hline ArticleGrants & $:$ & \\
\hline \hline ArticleContext & $:$ & 130591111 \\
\hline \hline
\end{tabular}




\section{William Wells}

Email: wells@biotext.com

Mouse models of cancer are primarily soft tissue sarcomas and lymphomas, whereas $90 \%$ of human cancers are epithelial in origin. In the August 10 Nature, Artandi et al. suggest that the difference arises from higher levels of telomerase (the enzyme that adds a protective cap on the end of chromosomes) in mice (Nature 2000, 406:641-645). When the researchers combine a mouse telomerase knockout with a mutation in the tumor suppressor p53, non-reciprocal translocations appear, followed by epithelial cancers. Artandi et al. believe that low levels of telomerase lead to genome rearrangements that initiate tumorigenesis, before subsequent telomerase reactivation saves the cells from excessive rearrangements that would cause self-destruction.

\section{References}

1. The role of p53 in tumour suppression: lessons from mouse models.

2. Nature magazine, [http://www.nature.com/nature/] 